Kraków

\title{
Od „arabskiej wiosny” do powstania „lajków” w kontekście współpracy Federacji Rosyjskiej i Unii Europejskiej
}

\begin{abstract}
Wstęp
Dod koniec 2011 roku miały miejsce istotne decyzje, które sygnalizują, że Stany Zjednoczone koncentrują swoją uwagę w rejonie Pacyfiku. Nasze trwate interesy w regionie Azji i Pacyfiku wymagaja naszej trwatej obecności w tym regionie [...] Stany Zjednoczone sq potęga Pacyfiku i jesteśmy tutaj, aby zostać [...] po tym jak zakończymy obecne wojny $i$ wycofywanie wojsk z Iraku i Afganistanu. [...] Rozkazałem mojemu zespołowi ds. bezpieczeństwa narodowego uczynienie priorytetu z obecności i misji $w$ regionie Azji i Pacyfiku [...] W efekcie, zmniejszenie wydatków na obronę w USA nie odbędzie się [...] kosztem regionu Azji i Pacyfiku1. 5 stycznia 2012 roku podczas przemówienia w Pentagonie Prezydent Barack Obama zapowiedział także ograniczenie zaangażowania w Europie. Z tą wypowiedzią harmonizuje deklaracja sekretarza generalnego NATO Andersa Fogha Rasmussena, który zaapelował do Rosjan: nie jesteśmy wrogami. Powinniśmy być partnerami ${ }^{2}$. Także Zbigniew Brzeziński włączając się w tę dyskusję stwierdził: ze względu na zagrożenie ekspansja z rejonu Pacyfiku [„Chindie” - przyp. M. L.], należy brać pod uwage w strategii rozwoju Unii Europejskiej wciaganie Rosji, poprzez Ukraine, do ścisłej wspótpracy ${ }^{3}$. Wspólnym mianownikiem tych wypowiedzi jest Rosja. W wyniku kryzysu zadłużeniowego oraz rosnącej potęgi Chin oraz Indii („Chindie” - 2,5 miliarda obywateli, trzecia część ludności świata), Stany Zjednoczone zamierzają zwiększyć swoje zaangażowanie w regionie Pacyfiku kosztem Europy. Jest to zapewne powód tak wielu pojednawczych gestów kierowanych w stronę Rosji, po raz pierwszy od czasu wojny w Gruzji w sierpniu 2008 roku. Współpraca zjednoczonej Europy oraz Federacji Rosyjskiej od lat coraz bardziej się zacieśnia. Jednak realizacja wizji Zbigniewa Brzezińskiego napotyka poważną przeszkodę, jaką jest niedemokratyczny system polityczny Federacji. Otworzenie nowego etapu współpracy w stosunkach europejsko-rosyjskich wymagałoby więc dopasowania standardów demokratycznych obu regionów. W sukurs przyszło społeczeństwo rosyjskie, które korzystając z możliwości nowych mediów mobilizuje się przeciwko fasadowej demokracji tandemu Miedwiediew-Putin. W kontekście szansy na zbliżenie Europy i Rosji, powstanie „lajków” zyskało więc zasadnicze znaczenie.
\end{abstract}

\footnotetext{
${ }^{1}$ CNN.com, wypowiedź prezydenta Baracka Obamy z 16 listopada 2011 wygłoszona podczas wizyty w Australii, gdzie USA budują w mieście Darwin nową bazę wojskową.

${ }^{2}$ Andres Fogh Rasmussen - sekretarz generalny NATO - wyraził tę opinię w odniesieniu do Rosji, na konferencji prasowej po spotkaniu z prezydent Litwy Dalią Grybauskaite w dniu 19 stycznia 2012 roku.

${ }^{3}$ Zbigniew Brzeziński wyraził tę opinię w wywiadzie udzielonym telewizji TVN w dniu 15 stycznia 2012 roku.
} 


\section{Wspólpraca UE-Rosja}

Federacja Rosyjska, ze względu na swoje znaczenie polityczne, gospodarcze i wojskowe jest naturalnym partnerem dla Unii Europejskiej. Już w okresie zimnej wojny, kooperacja energetyczna EWG ze Związkiem Radzieckim była negatywnie oceniana przez Stany Zjednoczone. Po upadku ładu bipolarnego, kraje Europy Zachodniej dążą do zacieśniania współpracy z Federacją. Szczególnie dwaj wiodący członkowie Unii Europejskiej - Francja oraz Niemcy - tradycyjnie inicjują projekty rozwijające kontakty z największym partnerem na wschodzie. W latach 90. XX wieku przejawem tych tendencji były francuskie postulaty powołania Stałej Rady NATO-Rosja, która miała stać się forum współpracy obu stron w wymiarze bezpieczeństwa. Perspektywy kooperacji politycznej były jednak wówczas utrudnione, głównie ze względu na słabość i niestabilność wewnętrzną Federacji. Zmieniło się to jednak na początku XXI wieku, kiedy do władzy doszedł Władimir Putin. Reformy polityczne i gospodarcze, które przeprowadził, zmierzały do wzmocnienia państwa i konsolidacji władzy Kremla. Działania te łączyły się jedank ze stopniowym demontażem mechanizmów demokratycznych, co nie wywoływało jednak większego sprzeciwu Zachodniej Europy. Pierwsza dekada XXI wieku przebiegła bowiem pod znakiem bezprecedensowego rozwoju współpracy europejsko-rosyjskiej w takich sprawach jak wojna z terroryzmem, wojna w Iraku, tarcza antyrakietowa czy współpraca gospodarcza i energetyczna. Świadczyły o tym niezwykle przyjazne relacje między politykami obu stron, w tym m.in. J. Chiraciem, G. Schroederem oraz W. Putinem. Symbolem tej przyjaźni stał się kontrowersyjny, poprowadzony po dnie Bałtyku gazociag Nordstream. Uwidocznił on, iż część krajów europejskich przedkłada przyjazne stosunki z Rosją nad solidarność w ramach Unii.

W relacjach dwustronnych pojawiały się jednak i kontrowersje. Początkowo wynikały one z różnicy zdań w kwestii irańskiego programu atomowego, bądź ,pomarańczowej rewolucji” na Ukrainie. Do przesilenia doszło jednak dopiero na tle wydarzeń w Gruzji w sierpniu 2008 roku. Część państw UE na czele z Polską ostro protestowało wobec działań wojsk Federacji, podczas gdy inne, w tym Francja i Niemcy zajęły dość dwuznaczne stanowisko. Był to kolejny dowód świadczący o woli Francji i Niemiec do utrzymania za wszelką cenę przyjaznych relacji z Moskwą. Fiasko wysiłków dyplomatycznego zakończenia konfliktu przez N. Sarkozy'ego oraz bezkarne działania rosyjskiej armii w Gruzji, jak zauważyło wielu komentatorów, doprowadziło jednak do sytuacji, w której prorosyjski żywioł w UE nieco stracił na znaczeniu ${ }^{4}$. Świadczyła o tym m.in. zgoda Europy Zachodniej na czasowe zawieszenie współpracy NATO-Rosja. Od 2008 roku, który mimo wszystko stał się momentem najpoważniejszego załamania dialogu Europy i Rosji, relacje te systematycznie się jednak poprawiały. Jak wskazano wyżej, bezprecedensowe deklaracje wielu politykow i politologów z końca 2011 roku udowodniły, iż w Europie Zachodniej istnieje chęć dalszego rozwijania współpracy z Federacją, szczególnie w kontekście powolnej zmiany akcentów w polityce amerykańskiej. Na przeszkodzie stoi tu jednak niedemokratyczny system polityczny, kontestowany od lat przez coraz liczniejszą opozycję. Dlatego wybuch społecznego niezadowolenia, w czym odegrały fundamentalną rolę tzw. nowe media, stał się szansą, ale jednocześnie i zagrożeniem dla relacji dwustronnych. Z jednej strony bowiem, powstanie „lajków” mogło być okazją na ponowną demokratyzację Rosji, a co za tym idzie, dalsze zbliżenie Federacji do UE zgodnie z wizją Z. Brzezińskiego. Z drugiej jednak strony, pojawiło się pytanie, czy wybuch

\footnotetext{
${ }^{4}$ Por. M. Lakomy, Geopolityczne aspekty wojny gruzińsko-rosyjskiej, „Przegląd Zachodni” 2010, nr 4.
} 
społecznego niezadowolenia będzie poparty przez kraje zachodnie na tej samej zasadzie, na jakiej popierały one rewolucje w świecie arabskim. Co więcej, wątpliwość ta zyskała na szczególnym znaczeniu w świetle bliskiej i przyjaznej współpracy europejskich elit politycznych $\mathrm{z}$ tandemem Miedwiediew-Putin.

\section{Geneza}

Rok 2011 przejdzie do historii jako rok zamieszek, które w wielu państwach arabskich przekształciły się w zbrojne walki pomiędzy lojalistami broniącymi autorytarnych reżimów i rebeliantami. Protesty przebiegały z różnym nasileniem i miały odmienny przebieg, chociaż ich wspólnym mianownikiem było społeczne niezadowolenie mające swoje źródła polityczne (ograniczone prawa obywatelskie, brak wolności, korupcja) i ekonomiczne (wysokie bezrobocie, bieda, brak perspektyw, niesprawiedliwy podział majątku narodowego). Najbardziej spektakularne zmiany, okupione krwawymi ofiarami, zaszły w Tunezji i Egipcie, gdzie doszło do oddania władzy przez dotychczasowych uzurpatorów. Z kolei w Libii interweniowało NATO, którego faktycznym celem stało się usunięcie Muammara Kadafiego. W tym przypadku możemy mówić o wojnie domowej. Podobna sytuacja wytworzyła się w Syrii - sąsiadującej z Państwem Izrael - co uczyniło tę krwawą rebelię niezwykle trudną do opanowania. Fenomenem tej fali niezadowolenia jest społeczna partycypacja, e-mobilizacja, która dokonała się w nowych mediach. Szczególnego znaczenia nabrały tutaj serwisy społecznościowe takie jak Facebook, Twitter, YouTube czy Flickr. Jednakże rolę detonatora odegrały depesze amerykańskich dyplomatów, opublikowane na portalu Wikileaks przez Juliana Assange’a, które potwierdzały wysoki stopień korupcji w państwach Bliskiego Wschodu.

Region ten jest obecnie terenem przełomowych zmian politycznych, jednakże ogólnoświatowy kryzys zadłużeniowy sprawił, iż mieliśmy do czynienia z eskalacją zamieszek do innych regionów świata. W sierpniu 2011 roku doszło do burd ulicznych o charakterze kryminalnym w Londynie i kilku innych miastach Wielkiej Brytanii. W rozniecaniu street riots, a później wyłapywaniu sprawców kradzieży i podpaleń pomogły filmy publikowane spontanicznie w YouTube. Najbardziej spektakularnym i nieoczekiwanym wydarzeniem był jednak tzw. „Ruch Oburzonych”. 15 października 2011 roku w 82 krajach i niemal 950 miastach jednocześnie odbyły się demonstracje uliczne, koordynowane na Facebooku, pod hasłami antykapitalistycznymi („Kapitalizm nie działa”) oraz solidarnościowymi. W Stanach Zjednoczonych ruch obywatelskiego nieposłuszeństwa, mający tam długie i chlubne tradycje, skierowany został przeciwko władzy Wall Street (We are 99\%, Occupy Wall Street). Protestujący oskarżali bankowców i korporacje o sprowokowanie globalnego kryzysu.

\section{Rosyjskie obawy}

W tych okolicznościach, w putinowskiej Rosji, dalekiej od modelu liberalnej demokracji, narodziła się obawa o zaszczepienie nastrojów antyrządowych w tym kraju. Z perspektywy zmasowanych ataków internetowych na serwery Estonii (2007 rok) i Gruzji (2008 rok), gdzie stroną atakującą była Rosja, kwestię militaryzacji cyberprzestrzeni i wykorzystania jej do mobilizacji i koordynacji masowych protestów antyrządowych, uznano za wysoce prawdopodobną. Podjęto próbę zapobieżenia ewentualnym konsekwencjom rozruchów inspirowanych na Facebooku i Twitterze. W tym celu Rada Bezpieczeństwa i Ministerstwo Spraw Zagranicz- 
nych Rosji, na zamkniętym spotkaniu szefów służb specjalnych i organów bezpieczeństwa z 52 państw w Jekaterynburgu, przedstawiło projekt konwencji ONZ O zapewnieniu międzynarodowego bezpieczeństwa informatycznego. W dokumencie tym zwrócono uwagę między innymi na następujące problemy: wykorzystanie technologii informacyjnych do wrogich działań i aktów agresji, podkopanie systemu politycznego, gospodarczego oraz społecznego, manipulowanie przepływem informacji w przestrzeni informacyjnej innych państw z zamiarem wypaczenia psychologicznego i duchowego społeczeństw, zmasowaną obróbkę psychologiczną ludności z zamiarem destabilizacji społeczeństwa i państwa, ingerencję w sprawy wewnętrzne innych państw przy pomocy serwisów społecznościowych i komunikatorów, obraźliwą lub wrogą propagandę $\mathrm{w}$ celu przeprowadzenia interwencji w sprawy wewnętrzne innych krajów ${ }^{5}$. Zwerbalizowane w dokumencie zagadnienia zapowiadają możliwość wprowadzania ograniczeń w dostępie do Internetu, co spotkało się ze zdecydowanym odporem Hillary Clinton, która stanęła w obronie polityki „Internet Freedom”, mimo iż Ameryka była w trakcie prac legislacyjnych nad ustawami SOPA, PIPA i ACTA, które masowo oprotestowali założyciele Wikipedii oraz użytkownicy Internetu (także w Polsce). Niepokój Rosji jest tym większy, że w sąsiedniej Białorusi przeciwnicy Aleksandra Łukaszenki wykorzystywali rosyjskie serwisy społecznościowe do organizowania politycznych flash mobów w postaci milczących marszów ${ }^{6}$. W efekcie Facebook i Twitter zostały w tym kraju wyłączone.

\section{Putinowska Rosja}

Władimir Putin wszedł na scenę polityczną pod koniec lat dziewięćdziesiątych XX wieku. Sytuacja gospodarcza Rosji pod rządami nieudolnego, choć bardzo zasłużonego dla demokracji Borysa Jelcyna, ulegała systematycznemu pogorszeniu, a prywatyzowany majątek narodowy był przejmowany za bezcen przez oligarchów. 17 sierpnia 1998 roku Rosja ogłosiła niewypłacalność, co pociągnęło za sobą między innymi upadek funduszu spekulacyjnego Long Term Capital Management. Dług w wysokości 51 miliardów dolarów przekraczał wówczas możliwości finansowe tego kraju, bowiem rezerwy zostały wyczerpane, a stan gospodarki był katastrofalny. Społeczeństwo rosyjskie popadło w biedę, nie wypłacano emerytur ani pensji, rosło bezrobocie, upadał postsowiecki model przemysłu. Realny stawał się czarny scenariusz dezintegracji państwa. W tej sytuacji 31 grudnia 1999 roku B. Jelcyn, w niejasnych okolicznościach, zrezygnował z urzędu, a pełniącym obowiązki prezydenta Federacji Rosyjskiej został były funkcjonariusz KGB, były szef FSB, ówczesny premier, Władimir Putin. Mandat ten potwierdził 26 marca 2000 roku w wyborach powszechnych, kiedy pokonał swoich przeciwników. Urząd prezydenta sprawował dwukrotnie do 7 maja 2008 roku, kiedy przesiadł się na fotel premiera, a władzę na Kremlu oddał swojemu przyjacielowi Dmitrijowi Miedwiediewowi. Zmiana konstytucji Federacji Rosyjskiej, której ostatecznie dokonano 30 grudnia 2008 roku, wydłużyła kadencję prezydenta Federacji z 4 do 6, zaś Dumy Państwowej do 5 lat $^{7}$. Dzięki tej nowelizacji Ustawy zasadniczej możliwy stał się powrót W. Putina na urząd prezydenta Federacji, który zaplanowano na marzec 2012 roku. W latach głębokiego kryzysu wydawał się on właściwym człowiekiem na trudne czasu. Swoją politykę oparł na

${ }^{5}$ V. Makarenko, Rosja chce móc odciać Internet, http://m.wyborcza.pl/wyborcza/1,105226,10346429, Rosja_odpowiada_na_polityke_wolnosci_sieci, 23.09.2011.

6 Ibidem.

${ }^{7}$ Oficjalna strona prezydenta Federacji Rosyjskiej, http://kremlin.ru/, 31.12.2011. 
sentymencie do Związku Radzieckiego i centralizacji władzy oraz powrocie do polityki mocarstwowości. Jego misją stało się podniesienie Rosji z kolan. Konsekwentna realizacja tego zamierzenia sprawiła, że Rosja dzisiaj dysponuje funduszem stabilizacyjnym przekraczającym 500 miliardów dolarów oraz minimalnym zadłużeniem. Powstają dwie ogromne inwestycje - Nord i South Stream do transportu gazu do Europy Zachodniej. Związki gospodarcze z Niemcami procentują transferem inwestycji i technologii. Rosja opanowała bardzo zaawansowaną produkcję własnych mikroprocesorów. W tym celu podjęto budowę rosyjskiej Doliny Krzemowej w Skołkowie pod Moskwa, gdzie inwestuje m.in. Microsoft. Modernizowane jest strategiczne uzbrojenie i wyposażenie armii (nowe rakiety taktyczne i strategiczne, nowe okręty podwodne itp.). W Obwodzie Swierdłowskim (Ural) powstaje „Tytanowa Dolina”. Działające tam przedsiębiorstwo Awisma współpracuje między innymi z Boeingiem przy produkcji niektórych elementów Dreamlinera. Na Dalekim Wschodzie Rosjanie budują nowy Kosmodrom Wastocznyj. W tym kontekście 16 stycznia 2012 roku na łamach dziennika „Izwiestija” opublikowano artykuł programowy W. Putina, kandydującego w marcowych wyborach prezydenckich. Sobie i grupie swoich współpracowników przypisał on wszystkie osiagnięcia Rosji od 1999 r., do których zaliczył wyprowadzenie kraju z wojny domowej, „przetrącenie kręgosłupa” terroryzmowi, odbudowanie integralności państwa i ładu konstytucyjnego, odrodzenie gospodarki i zapewnienie Rosji na przestrzeni 10 lat jednego z najwyższych w świecie wskaźników wzrostu gospodarczego ${ }^{8}$. W sferze społecznej dekada W. Putina zaowocowała ekspansją klasy średniej i rosnącym poziomem życia, ale także wszechobecną korupcją urzędników, samowolą policji, autorytaryzmem i niespełnionymi obietnicami. W sferze politycznej - wysokimi barierami wejścia dla ugrupowań opozycyjnych. Powołanie do życia nowej partii wymaga 45 tysięcy zapisanych członków, zaś próg wyborczy ustalono na poziomie $7 \%$.

\section{Suwerenna demokracja}

Rozpad Związku Radzieckiego, który dokonał się 8 grudnia 1991 roku dzięki inicjatywie Borysa Jelcyna (Rosja), Leonida Krawczuka (Ukraina) i Stanisława Szuszkiewicza (Białoruś) zburzył obowiązującą do tej pory w tym regionie ideologię komunistyczną. Ciekawostką jest to, że jak wynika ze wspomnień Szuszkiewicza, Związek Sowiecki rozwiązano niejako przez przypadek. Pierwotną przyczyną stały się problemy z dostawami ropy i gazu na Ukrainę i Białoruś. Zwiększenie dostaw wymagało decyzji Michaiła Gorbaczowa, co wydłużało proces decyzyjny w obliczu nadchodzącej zimy. Ominięcie prezydenta Związku było możliwe jedynie dzięki jego rozwiązaniu. Pamiętać należy, iż sygnatariuszami aktu jego narodzin były te same państwa. Pomysł spodobał się B. Jelcynowi co w konsekwencji doprowadziło do podjęcia ostatecznej decyzji. Michaił Gorbaczow zwlekał jeszcze do 26 grudnia kiedy to podał się do dymisji jako pierwszy i ostatni prezydent Związku Radzieckiego.

Lata 90. cechowały się w znacznym stopniu chaosem tak w kwestiach społecznych, gospodarczych, jak i ideologicznych. Dopiero przejęcie władzy przez Putina zainicjowało prace nad stworzeniem systemu politycznego, który mógłby komponować się z zachodnimi demokracjami, a jednocześnie nawiązywać do carskiego stylu sprawowania rządów, nie kolidując przy tym z żywą wciąż w społeczeństwie tęsknotą do Związku Radzieckiego. Kremlowscy

\footnotetext{
${ }^{8}$ Korespondent Wschodni, http://www.korespondent-wschodni.org/kategoria/rosja, 21.01.2012.
} 
ideologowie określili ją jako „suwerenną demokrację”. Nawiązuje ona do części europejskiej tradycji wyrosłej we Francji i w Niemczech. Jej istotą jest zapożyczona od Francois'a Guizota i Carla Schmitta specyficzna koncepcja reprezentacji politycznej: W kremlowskiej miksturze antyludowości Guizota i antyliberalizmu Schmitta wybory nie stuża do wyrażania różnych, często sprzecznych ze sobq interesów, lecz sq narzędziem stużacym pokazaniu identyczności rzadzacych i rzadzonych. Wybory nie stuż do reprezentowania ludzi, lecz do reprezentowania władzy przed ludźmi ${ }^{9}$. Kremlowscy ideolodzy - zdaniem Ivana Krasteva - zwrócili się ku intelektualnemu dziedzictwu kontynentalnej Europy - francuskiemu racjonalizmowi politycznemu i niemieckiemu decyzjonizmowi. Guizot i Schmitt to filary kremlowskiej idei suwerennej demokracji. Tym, co pociąga Moskwę u Guizota i Schmitta, jest ich antyrewolucyjność, która nabrała znaczenia po „pomarańczowej socjotechnice” na Ukrainie z 2004 roku, kiedy L. Kuczma został odsunięty od władzy ${ }^{10}$. Uzasadniona w ten sposób fasada demokracji dała podstawę do zawłaszczenia pełni władzy i sprawowania autorytarnych rządów przez W. Putina.

\section{Powstanie ,lajków"}

W międzyczasie dojrzało pokolenie hipsterów, anymainstreamowych młodych, wykształconych, zamożnych ludzi z dużych miast o hedonistycznym nastawieniu do życia, zainteresowanych muzyką, starymi samochodami i modą. W Rosji mówi się w tym kontekście także o pokoleniu „lajków”, czyli użytkowników serwisów społecznościowych. Oba te ruchy pozostają w opozycji do patriotycznych, wielkomocarstwowych dążeń klasy politycznej reprezentowanej przez działaczy „Jednej Rosji”, kontestującej wojnę ojczyźnianą i realizującej ideę Wielkiej Rosji. Pokolenie hipsterów i „lajków” to beneficjenci postępu, jaki dokonał się w dekadzie Putina, które jednak zdecydowało się wystapić przeciwko niemu w imię wolności i demokracji. Potwierdzają to statystyki. W czerwcu 2010 roku zanotowano tam 59700000 użytkowników Internetu co stanowiło 43\% populacji. Dla porównania w roku 2000 było zaledwie 3100000 użytkowników sieci, co stanowiło 2,1\% populacji ${ }^{11}$. Jeśli chodzi o Facebook (FB), to korzysta z niego obecnie 5237420 Rosjan $^{12}$. Największym jednak zainteresowaniem cieszy się rosyjski odpowiednik FB - Vkontakte.ru (VK), który miał w 2011 roku 13,09 miliona użytkowników ${ }^{13}$. Pochodzą oni głównie z dużych miast Zachodniej Rosji, szczególnie z Moskwy i Sankt Petersburga. Suwerenna demokracja wykreowana przez obóz Władimira Putina podporządkowała sobie media tradycyjne, stąd też Internet stał się platformą wolnej wypowiedzi nowego pokolenia Rosjan - hipsterów, „lajków” i „zniszczonych butów”. Ci ostatni to dobrze ubrani dwudziesto- i trzydziestolatkowie, którym nadano tę nazwę, ponieważ poświęcili swoje markowe obuwie, aby podczas deszczu, w błocie przyjść na mityng na Czystych Prudach w Moskwie 5 grudnia 2011 roku. Ten antykremlowski wiec zorganizowano w proteście przeciwko fałszowaniu wyborów do Dumy Państwowej, które odbyły się dzień wcześniej. Podczas prezentacji rozkładu poparcia w wyborczy wieczór, transmitowanego

${ }^{9}$ I. Krastev, Suwerenna demokracja, http://www.newsweek.pl/Europa/suwerenna-demokracja,44984,1,1.html, 21.01.2012.

${ }^{10}$ I. Krastev, Suwerenna demokracja, http://Newsweek.pl, 22.01.2012.

${ }^{11}$ Internet World Stats, http://www.internetworldstats.com/europa2.htm\#ru, 31.12.2011.

${ }^{12}$ Socialbakers, http://www.socialbakers.com/facebook-pages/, 31.12.2011.

13 Alexa. The Web information Company, http://www.alexa.com, 31.12.2011. 
przez państwową telewizję informacyjną Rossija 24, doszło do skandalu. Prezenterka, omawiając wyniki, które wizualizowano na dużym ekranie w studiu zauważyła, że w obwodzie rostowskim na wszystkie partie oddano w sumie 146,47\% głosów. „Jedna Rosja” otrzymała 58,99\%, KPRF - 32,96\%, LDPR - 23,74\%, „Sprawiedliwa Rosja” - 19,41\%, „Jabłoko” - 9,32\%, „Patrioci Rosji” - 1,46\% i „Słuszna Sprawa”- 0,59\%. Podobne niespodzianki pojawiły się również w Swierdłowsku, gdzie suma głosów wyniosła $115 \%$ oraz w Woroneżu - 129\%, zaś w Czeczenii i Dagestanie oddano niemal 100\% głosów na „Jedną Rosję”.

\section{Nowe media}

W tych okolicznościach podniosła się fala oburzenia. Szczególną rolę odegrał tu rosyjski Internet, który zaczął zapełniać się dowodami fałszerstw. Użytkownicy umieszczali na Facebooku nagrania z lokali wyborczych, zdjęcia podmienionych protokołów głosowania. W dyskusjach informowano o atakach hakerów na strony internetowe opozycyjnych partii politycznych i organizacji pozarządowych. Prezentowano wyniki exit polls realizowane przez niezależne ośrodki badawcze, które wskazywały na znacznie niższe poparcie dla partii tandemu Putin-Miedwiediew. Pospolite ruszenie Internautów, którzy zebrali się na Czystych Prudach, Placu Triumfalnym oraz Placu Bołotnym składało się, zdaniem socjologa Aleksieja Lewinsona z Centrum Lewandy, $\mathrm{z}$ dwóch grup. Pierwsza to przedstawiciele tak zwanej niesystemowej opozycji, weterani tego rodzaju protestów. Druga, liczniejsza, to członkowie internetowych społeczności. Ludzie, którzy dotad rzadko przejawiali społeczna aktywność w realnym świecie, a już na pewno nie z powodu polityki. Tym razem zdecydowali się otwarcie zaprotestować przeciwko władzy. [...] Społeczeństwo zaczyna się oddolnie organizować, choć daleko mu jeszcze do masowego ruchu jakim była polska Solidarnośćc ${ }^{14}$.

Demonstracje przebiegały pokojowo, według instrukcji w stylu Gandhiego, zamieszczonej na blogu Lady Spring, co nawiązywało do arabskich rewolucji. Zaapelowano tam: KAŻDEMU policjantowi o ludzkiej twarzy i ludzkim zachowaniu mówcie DZIĘKUJE, mówcie: rozumiemy, że wypetniacie swoje obowiazki - mamy nadzieję zmienić wam zwierzchników żebyście przestali być ich niewolnikami. Oni NAJBARDZIEJ się boja tego, że na ulice wyjda kulturalni, inteligentni i uprzejmi ludzie, którzy MAJA DOŚĆ. I którzy gotowi sq na PRAWNE działania. I jeśli żadamy ponownych wyborów - TO MAMY RACJE. Nie łamcie prawa, nie używajcie przemocy. Nie jesteśmy stadem, jesteśmy OBYWATELAMI ${ }^{15}$. Innym słynnym internauta, który zaangażował się w powstanie „lajków” był bloger Falkon, który oferował porady prawne dla manifestantów. Podzielił on je na cztery kategorie: „przed akcją", „zatrzymanie”, ,po zatrzymaniu” i „w sądzie”. Przed akcją radzi skopiować swój paszport, kopię przy tym najlepiej poświadczając u notariusza. Ponadto, namawia do upoważnienia innej osoby do pełnomocnictwa i reprezentowania go w przypadku aresztowania. Informuje także o funkcjonującym od niedawna prawie do wykonania telefonu w trakcie aresztowania. Radzi także o zabraniu ciepłego ubrania, taniego telefonu komórkowego, tabliczki czekolady i pozostawieniu w domu cennych przedmiotów ${ }^{16}$. Sceptyczny Internauta Dark Secret poddał jednak w zwątpienie autentyczność ruchu pisząc: Radio »Svoboda « realizowało przekaz z Placu Bołotnego. Radio to jest niekomercyjna stużba finansowana przez

\footnotetext{
${ }^{14}$ K. Kwiatkowska, Powstanie Lajków, „Polityka”, nr 51 (2838), 14.12-20.12.2011, s. 51.

${ }^{15}$ Lady Spring blog, 6.01.2012.

${ }^{16}$ Por. Falcon blog, LiveJournal.com, 7.01.2012.
} 
Kongres USA. Organizacje »Gołos" finansuja Stany Zjednoczone. Amerykanie chca aby w wyborach w 2012 roku nie zwyciężyt Putin ${ }^{17}$. Dyskusja o polityce rozgorzała także na popularnym w Rosji portalu snob.ru. Wynika z niej, że mimo świeżości ruchu społeczeństwo rosyjskie wciąż posługuje się retoryką komunistyczną. Dzięki Internetowi udało się dotrzeć do opinii publicznej poza systemowej opozycji, pozbawionej dostępu do kontrolowanej przez Kreml telewizji, mobilizując najbardziej niezadowolonych z rządów W. Putina. Wspomniana organizacja „Gołos" ${ }^{18}$, która podjęła się monitorowania naruszeń w trakcie wyborów do Dumy w 2011 roku naliczyła ich i opublikowała na swojej stronie internetowej aż $7790^{19}$ (wirtualna karta naruszeń ordynacji wyborczej). Aleksander Nawalny - prawnik znany jako demaskator korupcji - opublikował na swoim blogu w serwisie Live Journal (LJ) ${ }^{20}$ serię wpisów pod tytułem: Jedna Rosja - partia żulików i złodziei ${ }^{21}$. Hasło to stało się równie popularne jak jego autor, który od tej chwili jest represjonowany przez władze. W serwisie LJ, w Rosji nazywanym ŻŻ (Żyvoj Żurnal), funkcjonuje obecnie 45,2 miliona blogów i grup. Codziennie dokonywanych jest około 120 tysięcy nowych wpisów. Jest to zatem poważna platforma komunikacji politycznej, podobnie jak Facebook i Vkontakte, gdzie zamieszczały swoje programy wyborcze partie niedopuszczone do głosowania. Portale te posłużyły także do spontanicznej mobilizacji uczestników demonstracji. Chęć uczestnictwa w jednej z nich z 10 grudnia 2011 roku potwierdziło ponad 50 tysięcy „lajków”, którzy jednocześnie popierają żądania powtórnych wyborów. Znaczącą rolę odegrały także telefony komórkowe, którymi dokumentowano fałszerstwa. Zdjęcia i filmy stanowiące dowody przestępstw umieszczano w Internecie, szczególnie w serwisie YouTube ${ }^{22}$ oraz $\mathrm{VK}^{23}$. Jednym z kanałów wolnej telewizji stał się należący do Natalii Sindeevej - Dożd. Optimistic Channel.

Wzorem innych krajów Rosjanie jako swój symbol i znak rozpoznawczy wybrali białe wstążeczki. Przymocowywali je do piersi, do rąk, plecaków czy klamek samochodowych. Powstały w ten sposób logotyp obrazujący literę V (Victory - zwycięstwo) miał symbolizować ruch występujący pod nazwą ,Solidarności”, który nawiązuje w ten sposób do polskich doświadczeń z lat osiemdziesiątych XX wieku.

\section{Opinia publiczna}

Ruch „Solidarności” jest firmowany przez Garri Kasparowa i Borysa Niemcowa. Niestety w społeczeństwie rosyjskim nie jest dobrze postrzegany. Według sondażu państwowego ośrodka badawczego WCIOM z 7-8 stycznia 2012 roku B. Niemcow otrzymał $0 \%$ poparcia. Tymczasem ranking pozostałych kandydatów wyglądał następująco ${ }^{24}$ : W. Putin $-48 \%$, G. Zjuganow - 10\%, W. Żyrinowski - 9\%, S. Mironow - 5\%, G. Jawliński - 2\%, D. Rogozin $-0 \%$, M. Prochorow $-3 \%$, A. Nawalny $-0 \%$, J. Szewczuk $-0 \%$. Ciekawe dane prezentował

\footnotetext{
${ }^{17}$ Dark Secret, http://vk.com, 7.01.2012.

${ }^{18}$ ГОЛОС, http://www.golos.org, 6.01.2012.

${ }^{19}$ Strona internetowa: http://www.kartanarushenij.ru, 6.01.2012.

${ }^{20}$ Od 13 lutego 2007 roku jest to rosyjska platforma blogowa odkupiona od amerykańskiej SixApart przez kompanię SUP.

${ }^{21}$ A. Nawalny, Jedna Rosja - partia żulików i złodziei, http://navalny-army.livejournal.com, 7.01.2012.

${ }^{22}$ Youtube.com, http://www.youtube.com/watch?v=leGvmpMlrBY\&featu, http://www.youtube.co./watch? $\mathrm{v}=$ 3d16N4Q2pRw, 7.01.2012.

${ }^{23}$ Vk.com, http://vkontakte.ru/video11201027161354580, 7.01.2012.

${ }^{24}$ Strona internetowa, http://www.publicast.ru/theme/id/828/, 23.01.2012.
} 
sondaż wyborczy zrealizowany przez niezależne Centrum Lewandy w dniach 16-20 grudnia 2011 roku, a więc w okresie szczytowej mobilizacji rosyjskiej opozycji po feralnych wyborach do Dumy Państwowej. Na W. Putina zamierzało wówczas głosować 36\% badanych zaś $13 \%$ deklarowało, że nie odda głosu na niego pod żadnym warunkiem. 75\% respondentów było pewnych jego zwycięstwa, mimo iż 46\% Rosjan spodziewało się fałszerstw. Ciekawa jest kwestia zachowawczości Rosjan. Potrzebę powstania nowych partii widziało tylko $26 \%$ badanych, a zdaniem $48 \%$ nie są one potrzebne. Sympatię do liderów niesystemowej opozycji deklarowało tylko $12 \%$ respondentów. Po doświadczeniach lat 90 . Rosjanie są powściągliwi w stosunku do modelu demokracji liberalnej w stylu zachodnim ${ }^{25}$.

\section{Podsumowanie}

Powstanie „lajków” w Rosji przebiegało w czasie, gdy przywódcy państw Unii Europejskiej, zwłaszcza jej trzonu, czyli strefy euro, koncentrowali się na kwestii ratowania Grecji oraz wspólnej waluty. Ich uwaga kierowała się na sprawy unijne. Dla większości państw europejskich Rosja jest ważnym partnerem handlowym (energetyka, inwestycje). Stąd też pragmatyzm w relacjach dwustronnych okazał się ważniejszy niż kwestia przestrzegania praw obywatelskich czy stan demokracji w Rosji. Pod tym względem nie pojawiły się żadne nadzwyczajne reakcje ze strony państw zachodu poza bezosobową rezolucją Parlamentu Europejskiego z 14 grudnia 2011 roku ${ }^{26}$ oraz krytyczną oceną sekretarz stanu USA Hillary Clinton podczas spotkania ministerialnego OBWE w Wilnie. Reakcje pochodziły głównie ze strony mediów, które obficie informowały opinię publiczną Europy o największym buncie Rosjan skierowanym przeciw Putinowi. Porównując zaangażowanie Unii w promocję demokracji w świecie arabskim trzeba stwierdzić, iż Rosjan pozostawiono w zasadzie bez wsparcia zewnętrznego.

W związku z powyższym należałoby stwierdzić iż:

1) powstanie „lajków” było bezprecedensowym wydarzeniem wymierzonym w Władimira Putina. W odróżnieniu od pomarańczowej rewolucji na Ukrainie oraz rewolucji arabskich powstanie „lajków” nie odniosło sukcesu;

2) współpraca przez Internet to cecha charakterystyczna wszystkich buntów i masowych ruchów w ostatnich latach, zwłaszcza w państwach arabskich. Umożliwia ona partycypację w demokracji, zwłaszcza tam, gdzie off-line jest ona ograniczona lub niemożliwa;

3) UE chce współpracować i zacieśniać współpracę z Rosją, ale nie za cenę poparcia ruchów demokratycznych/powstania „lajków” w tym kraju, na tej samej zasadzie jak w krajach arabskich. Co za tym idzie, zbliżenie na zasadach postulowanych przez Z. Brzezińskiego jest obecnie mało realne;

4) doświadczenia ruchów prodemokratycznych z ostatnich lat, wykorzystujących narzędzia on-line, dowodzą, że sukces możliwy jest wówczas, gdy zostanie zastosowana strategia masowych, oddolnych nacisków ludowych oraz odgórnych, międzynarodo-

\footnotetext{
${ }^{25}$ O. Nadskakuła, Rosjanie nie chcq demokracji na wzór zachodni, http://www.przeglad-tygodnik.pl/artykul/rosjanie-nie-chca-demokracji-na-wzor-zachodni, 23.01.2012.

${ }^{26}$ Pełny tekst rezolucji Parlamentu Europejskiego z 14 grudnia 2011 roku, http://www.europarl.europa.eu/sides/getDoc.do?pubRef=-//EP//TEXT+TA+P7-TA-2011-0575+0+DOC+XML+V0//PL\&language=PL.
} 
wych, jak w przypadku Libii. Taka strategia jednakże w przypadku Rosji byłaby wielce ryzykowna dla Unii Europejskiej.

\section{Bibliografia}

Korespondent Wschodni, http://www.korespondent-wschodni.org/kategoria/rosja.

Krastev I., Suwerenna demokracja, http://www.newsweek.pl/Europa/suwerenna-demokracja,44984,1,1.html.

Kwiatkowska K., Powstanie Lajków, „Polityka”, nr 51 (2838), 14.12-20.12.2011.

Lakomy M., Geopolityczne aspekty wojny gruzińsko-rosyjskiej, „Przegląd Zachodni” 2010, nr 4.

Makarenko V., Rosja chce móc odciqć Internet, http://m.wyborcza.pl/wyborcza/1,105226,10346429,Rosja_odpowiada_na_polityke_wolnosci_sieci.

Nadskakuła O., Rosjanie nie chcq demokracji na wzór zachodni, http://www.przeglad-tygodnik.pl/artykul/rosjanie-nie-chca-demokracji-na-wzor-zachodni.

Nawalny A., Jedna Rosja - partia żulików i złodziei, http://navalny-army.livejournal.com.

Rezolucja Parlamentu Europejskiego z 14 grudnia 2011 roku, http://www.europarl.europa.eu/sides/getDoc.do?pu$\mathrm{bRef}=-/ / \mathrm{EP} / / \mathrm{TEXT}+\mathrm{TA}+\mathrm{P} 7-\mathrm{TA}-2011-0575+0+\mathrm{DOC}+\mathrm{XML}+\mathrm{V} 0 / / \mathrm{PL} \&$ language $=\mathrm{PL}$.

Inne źródła internetowe.

\section{From the Arab Spring to the uprising of the 'likers' in the context of cooperation between the Russian Federation and the European Union}

\section{Summary}

2011 started with the Arab Spring and ended with Putin's fall said one user of Russian equivalent of Facebook - Vkontake.ru. Around 3,000 more or less serious election frauds identified in the course of the elections to Russian parliament, the Duma, on December 4, 2011 triggered a revolt. Russians did what their predecessors in the authoritarian Arab states, Tunisia, Egypt and Libya, had done. After a heated discussion in the new media they took to the streets in Moscow and St. Petersburg. The blogosphere created Alexei Navalny, who called „United Russia” a party of crooks and thieves. The strongest movement of resistance against the Putin - Medvedev tandem involved young people, whose campaign was named the uprising of 'likers'. 